phones can be put do not require students to use their phones in school. So even in schools and classrooms where cell phones are not permitted on the premises, students can still be using their phones and connectivity for educational purposes. The range of uses is vast. For example, teachers can use broadcast text messages to students as reminders about assignments. And students can capture photos and videos for projects and then email the image files to themselves at school-based email accounts that they can access during school to retrieve the images for media projects. The possibilities for connecting cell phones and learning are virtually unlimited.

Liz Kolb's blog site (www.cellphonesinlearning.com) is worth mentioning as a resource for teachers to explore the educational possibilities of cell phones and to exchange information. It is called "From Toy to Tool: Cell Phones in Learning," based around ideas in the book mentioned earlier. Also, an Internet search on "cell phones in education" or similar keywords will yield a wealth of ideas that can be used or adapted - including advice about how to counteract the negative potential of cell phones, a hot topic that encompasses everything from how to keep students from texting in class when they should be paying attention to how to curb socalled sexting (students sending sexually explicit photos and messages to one another). Many educators realize that the potential gains for student learning outweigh the negatives.

Each installment in this six-part series of articles ends with a question. Here is the question for this is- sue: Do you and your students use cell phones for sharing ideas, information, or products to enhance creativity and build knowledge? If so, how? What advice would you give your colleagues? Share your ideas by posting on the Tech-Savvy Teaching blog (http://www.blogcatalog.com/blogs/ tech-savvy-teachers/posts/) and let others read how you do it. You also might find something to inspire you in the experiences of your colleagues.

\section{Reference}

Kolb, L. (2008). Toys to tools, Connecting student cell phones to instruction. Eugene, OR: ISTE

Donovan R. Walling is a longtime educator, writer, and editorial consultant. His most recent book is Writing for Understanding: Strategies to Increase Content Learning, published

\title{
The History Corner
}

\section{Was this used in the classroom?}

\author{
By Rebecca P. Butler
}

$\mathbf{T}$ he RCA M-1 Wire Recorder is a sound recorder circa 1948. While we are unsure if this exact wire recorder -- a precursor to today's audio recording devises -- was used in classrooms, we do know that such recorders were used to teach in $\mathrm{K}-12$ and higher education. One high school student recalls that he worked in the early fifties at the University of Miami recording students in speech classes. Part of his job description was transcribing student speeches from wire to Presto disks. (Veritas, 1999). Another former student recalls his elementary teacher in the1940s setting up a wire recorder in the classroom so that the students might record

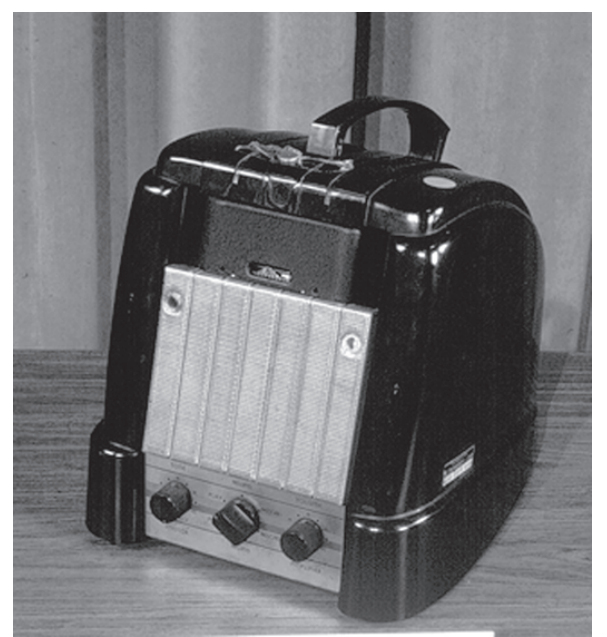

Lee and Lida Cochran AECT Archives, Blackwell Museum of Education

Northern Illinois University, 1999

themselves. (Quiggenbottom, 2001). The wire recorder, which was quite practical for the mid-1900s, made it easier for teachers to experiment with recording their students. Often such recording was a classroom first.

\section{References}

Bushong, R.H. (2003). AECT Archives' Paper. DeKalb, Illinois: ETT 640, Northern Illinois University.

Lee and Lida Cochran AECT Archives. (1999). RCA M-1 Wire Recorder. DeKalb, Illinois: Blackwell Museum of Education, Northern Illinois University. Retrieved from

http://www.cedu.niu.edu/blackwell/multimedia/high/VT/100.html

Quiggenbottom. (2001). My story: Off topic. Retrieved from http://www.volusiaowners.com/articles/article.asp? ID =12

Veritas. (1999). After 47 years of service, Hayman's seen it all. Retrieved from http:// www.miami,edu/veritas/feb99/class.html 